\title{
Insulin resistance in Type 1 (insulin-dependent) diabetes following hypoglycaemia - evidence for the importance of $\boldsymbol{\beta}$-adrenergic stimulation
}

\author{
S. Attvall ${ }^{1}$, J.Fowelin ${ }^{1}$, H. von Schenck ${ }^{2}$, I. Lager ${ }^{1}$ and U.Smith ${ }^{1}$ \\ ${ }^{1}$ Department of Medicine II, Sahlgren's Hospital, Gothenburg and \\ ${ }^{2}$ Department of Clinical Chemistry, University of Linköping, Linköping, Sweden
}

\begin{abstract}
Summary. The insulin effect, evaluated with the euglycaemic clamp technique, was studied before and after hypoglycaemia in 7 patients with Type 1 (insulin-dependent) diabetes. Following an initial $2 \mathrm{~h}$ clamp (clamp I) hypoglycaemia was induced and $2 \mathrm{~h}$ later a second clamp (clamp II), identical to the former, was performed. Each subject was studied twice; during infusion with saline (placebo) or propranolol. Glucose production and disposal were studied with the $3\left({ }^{3} \mathrm{H}\right)$ glucose technique. During placebo infusion, hypoglycaemia elicited an insulin resistance leading to approx. 50\% reduction in the steady state glucose infusion rate during clamp II as compared to clamp I (clamp I $2.58 \pm 0.32$, clamp II $1.26 \pm$ $\left.0.08 \mathrm{mg} \cdot \mathrm{kg}^{-1} \cdot \mathrm{min}^{-1}, p<0.02\right)$. The insulin resistance was prevented by infusing propranolol (clamp I $2.29 \pm 0.29$, clamp II $2.85 \pm 0.56 \mathrm{mg} \cdot \mathrm{kg}^{-1} \cdot \mathrm{min}^{-1}$ ). The posthypoglycae-
\end{abstract}

mic insulin resistance was due to a less pronounced insulin effect on both glucose production (clamp I $0.29 \pm 0.21$, clamp II $\left.0.86 \pm 0.19 \mathrm{mg} \cdot \mathrm{kg}^{-1} \cdot \mathrm{min}^{-1}, p<0.05\right)$ and glucose utilisation (clamp I $2.84 \pm 0.26$, clamp II $2.13 \pm 0.23 \mathrm{mg}$. $\mathrm{kg}^{-1} \cdot \min ^{-1}, p<0.05$ ). The insulin resistance on both glucose production and utilisation was prevented by propranolol. Thus, the present study demonstrates that hypoglycaemia elicits a prolonged insulin resistance which is due to a less pronounced effect of insulin to both inhibit splanchnic glucose production and to stimulate peripheral glucose utilisation. The insulin resistance is due to $\beta$-adrenergic stimulation and can be prevented by propranolol.

Key words: Hypoglycaemia, insulin resistance, Type 1 (insulin-dependent) diabetes, propranolol.
Instability of the metabolic control is a common problem in Type 1 (insulin-dependent) diabetes. Episodes of hypoglycaemia may frequently be followed by periods of hyperglycaemia. Different mechanisms for the posthypoglycaemic hyperglycaemia, the so-called Somogyi effect, have been proposed. Somogyi himself [1] suggested that increased release of adrenaline was probably the most important reason. However, hypoglycaemia also leads to the release of other counterregulatory hormones, such as glucagon, cortisol and growth hormone [2, 3], all of which influence glucose turnover and tend to increase glucose levels $[4,5]$.

Waning of the insulin effect, rather than an effect of the counterregulatory hormones per se, may cause the posthypoglycaemic hyperglycaemia. This possibility is supported by the observation that no correlation was found between the release of counterregulatory hormones and the subsequent rise in blood glucose levels $[6,7]$. Excessive carbohydrate intake in connection with the hypoglycaemia would further augment the tendency for hyperglycaemia.

The goal of modern diabetes treatment is to intensify metabolic control. However, with the current thera- peutic arsenal hypoglycaemic episodes may then become a frequent problem [8,9]. It is, therefore, important to clarify the mechanisms responsible for the rebound hyperglycaemia and to establish means whereby it can be prevented. The present study was carried out to test the hypothesis that hypoglycaemic episodes are followed by insulin resistance which may be important for the rebound hyperglycaemia. The euglycaemic clamp technique has been used to quantify the insulin effect in order to avoid the influence of high glucose levels on glucose production and uptake.

\section{Subjects and methods}

\section{Subjects}

Seven Type 1 diabetic patients, characterised according to the criteria of the National Diabetic Data Group [10], were studied. The postabsorptive plasma C-peptide levels were $0.02 \mathrm{nmol} / 1$ or lower in all patients. They were all treated with continuous subcutaneous insulin infusion (Nipro SP3, Meda AB, Gothenburg, Sweden and Nordisk Infuser, Nordisk Gentofte, Copenhagen, Denmark) for 2-24 months. None of the patients had any clinical or laboratory evi- 
Table 1. Characteristics of the patients

\begin{tabular}{|c|c|c|c|c|c|c|c|c|}
\hline Sex & $\begin{array}{l}\text { Age } \\
\text { (years) }\end{array}$ & $\begin{array}{l}\text { Weight } \\
\text { (kg) }\end{array}$ & $\begin{array}{l}\text { Height } \\
(\mathrm{cm})\end{array}$ & $\begin{array}{l}\text { Body mass } \\
\text { index (BMI) } \\
\mathrm{kg} / \mathrm{m}^{2}\end{array}$ & $\begin{array}{l}\text { Diabetes } \\
\text { duration } \\
\text { (years) }\end{array}$ & $\begin{array}{l}\text { Daily insulin } \\
\text { dose } \\
(\mathrm{IU} / \mathrm{kg})\end{array}$ & $\begin{array}{l}\mathrm{HbA}_{1 \mathrm{c}}{ }^{\mathrm{a}}(\%) \\
\text { Placebo }\end{array}$ & $\begin{array}{l}\text { Pro- } \\
\text { pranolol }\end{array}$ \\
\hline F & 26 & 63 & 170 & 36.6 & 14 & 0.77 & 7.2 & 6.8 \\
\hline M & 30 & 77 & 174 & 40.3 & 12 & 0.56 & 6.2 & 6.8 \\
\hline M & 34 & 75 & 182 & 38.5 & 15 & 0.59 & 6.7 & 7.3 \\
\hline $\mathbf{M}$ & 35 & 72 & 179 & 37.9 & 10 & 0.59 & 7.2 & 6.1 \\
\hline Mean $\pm S D$ & $32 \pm 6$ & $71 \pm 9$ & $175 \pm 9$ & $38.1 \pm 2.2$ & $13 \pm 3$ & $0.62 \pm 0.08$ & $7.2 \pm 0.7$ & $7.0 \pm 0.6$ \\
\hline
\end{tabular}

a Upper limit of normal range for $\mathrm{HbA}_{1 \mathrm{c}}$ is $5.4 \%$

Time

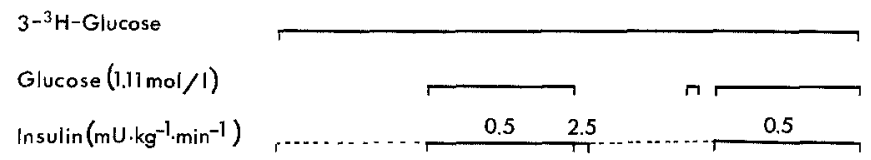

Placebo, Propranolol

Fig. 1. Experimental design. The subjects were either treated with saline (placebo) or propranolol from the beginning of euglycaemic clamp I throughout the length of the study

dence of autonomic neuropathy demonstrable with the immediate heart-rate response to standing [11] or heart-rate variations to deep breathing [12]. Their metabolic control was considered good and was continuously evaluated with home glucose monitoring and $\mathrm{HbA}_{1 \mathrm{c}}$ levels. The characteristics of the patients are shown in Table 1. Informed consent was obtained from all subjects and the study was approved by the Ethical Committee of the University of Gothenburg.

\section{Infusions}

All infusions were made through a catheter in a cubital vein. Arterialised blood samples were drawn from a dorsal hand vein in the contralateral arm. Both arms were warmed with electrical pads to increase the blood flow. Insulin (Actrapid MC, Novo, Copenhagen, Denmark) was infused at a concentration of $40 \mathrm{mU} / \mathrm{ml}$ in isotonic saline with $4 \mathrm{mg} / \mathrm{ml}$ albumin added to prevent glass adhesion. Glucose $(1.11 \mathrm{~mol} / 1)$ was infused at variable rates in the same catheter as the insulin. Potassium chloride $(0.1 \mathrm{mmol} / \mathrm{ml})$ was infused at a rate of $7 \mathrm{mmol} / \mathrm{h}$ to prevent hypokalaemia. Placebo (saline) or propranolol $(5 \mathrm{mg}$ intravenously followed by $4.8 \mathrm{mg} / \mathrm{h}$ ) were infused in the same catheter as the insulin and glucose. Rates of glucose appearance and disposal were determined by the infusion of $\mathrm{D}-\left(3-{ }^{3} \mathrm{H}\right)$ glucose (New England Nuclear, Boston, Mass, USA) dissolved in saline. A primed infusion of $25 \mu \mathrm{Ci}$ was given followed by a constant infusion of $15 \mu \mathrm{Ci} / \mathrm{h}$.

\section{Study design}

The design of the study is shown in Figure 1. Continuous subcutaneous insulin infusion was interrupted at 21.00 hours the evening before the study. The blood glucose levels were checked during the night and regulated with a slow continuous intravenous insulin infusion. On the morning of the study, at 08.00 hours, the patients were admitted to the laboratory in the postabsorptive state and D- $\left(3-{ }^{3} \mathrm{H}\right)$ glucose was infused for $120 \mathrm{~min}$ to achieve isotopic equilibration. Euglycaemia was maintained during this equilibration period by a slow intravenous insulin infusion (placebo $10 \pm 1$, propranolol $11 \pm 1 \mathrm{mU} \cdot \mathrm{kg}^{-1} \cdot \mathrm{h}^{-1}$ ). A euglycaemic clamp (clamp I) was then started with a primed insulin infusion for $10 \mathrm{~min}$ as described by DeFronzo et al. [13] followed by a constant infusion of $0.5 \mathrm{mU} \cdot \mathrm{kg}^{-1}$. $\min ^{-1}$ for $120 \mathrm{~min}$. Arterialised venous blood was used to measure the glucose concentration every $5 \mathrm{~min}$ with a reflectometer (Reflomat, Clinicon International, Mannheim, FRG, correlation with glucose levels with the glucose oxidase technique; $r=0.99$ ). The rate of glucose infusion was then adjusted to maintain the glucose levels at $4.5 \mathrm{mmol} / 1$. The clamp was performed for $120 \mathrm{~min}$. The glucose in fusion was then stopped and the insulin infusion rate increased to $2.5 \mathrm{mU} \cdot \mathrm{kg}^{-1} \cdot \mathrm{min}^{-1}$ for $10 \mathrm{~min}$ to induce hypoglycaemia. Following this, the insulin infusion rate was for $100 \mathrm{~min}$ reverted to that which was used to maintain euglycaemia during the isotopic equilibration period. The glucose levels were continuously followed with the reflectometer during the hypoglycaemia and the glucose counterregulation. Ninety min after the induction of the hypoglycaemia glucose was given for $10 \mathrm{~min}$ to restore euglycaemia ( $4.5 \mathrm{mmol} / \mathrm{l})$. After $10 \mathrm{~min}$ stabilisation a second euglycaemic clamp (clamp II), identical to the first, was performed. Each subject was studied twice in a randomised order with infusion of saline (placebo) or propranolol ( $5 \mathrm{mg}$ intravenously followed by $4.8 \mathrm{mg} / \mathrm{h}$ ). The saline and propranolol infusions were started at the beginning of clamp I and were continued throughout the study. The two studies were performed with at least a 4 week interval. The coefficients of variation for the glucose levels during the clamps were; placebo clamp I $3.7 \pm 0.6$, clamp II $6.6 \pm 0.6$; propranolol clamp I $5.5 \pm 0.8$, clamp II $5.6 \pm 0.8 \%$.

\section{Analytical procedures}

During the isotopic equilibration period blood samples were taken before (at zero time), after $80 \mathrm{~min}$ and every $20 \mathrm{~min}$ thereafter for chemical determination of glucose and measurement of specific activity. Blood samples for the determination of levels of free insulin, catecholamines, glucagon, cortisol and growth hormone were drawn as shown in the Results. All samples were kept on ice, rapidly centrifuged and the plasma stored at $-20^{\circ} \mathrm{C}$ until analysed.

The glucose levels shown in the Results were determined with the glucose oxidase technique (Kabi Diagnostics, Uppsala, Sweden). Measurements of the specific activity of glucose were performed on the samples after deproteinisation of plasma with $\mathrm{Ba}(\mathrm{OH})_{2}$ and $\mathrm{ZnSO}_{4}$ and evaporation at $40^{\circ} \mathrm{C}$. The samples were counted in a Packard Liquid Scintillation counter for $20 \mathrm{~min}$. The free insulin levels were determined on the supernatant of polyethyleneglycol-treated samples [14] with a radioimmunoassay technique (Phadeseph Insulintest, Pharmacia, Uppsala, Sweden). C-peptide was measured with a radioimmunoassay technique (Novo, Denmark). Glucagon was assayed with antiserum E7 [15]. This antiserum, which recognises the carboxy-terminal region of glucagon, has been characterised with antiserum $30 \mathrm{~K}$ as reference [16]. Catecholamines were de- 
termined with an isotope radioenzymatic method as modified by Eriksson et al. [17]. Cortisol was determined with a fluorimetric method and growth hormone with a double antibody technique. Glycosylated hemoglobin levels $\left(\mathrm{HbA}_{1 \mathrm{c}}\right)$ were determined with a high performance liquid chromatographic technique [18]. The insulin and glucagon levels during the euglycaemic clamp shown in the Results are the mean values of three samples collected with an interval of $20 \mathrm{~min}$ during the second hour of each clamp period and the adrenaline, cortisol and growth hormone levels the mean values of two samples collected with an interval of $30 \mathrm{~min}$ during the second hour of each clamp period.

\section{Calculations}

The rates of glucose production $\left(R_{z}\right)$ and utilisation $\left(R_{d}\right)$ were calculated with the non-steady-state equations of De Bodo et al. [19]. This method assumes that rapid changes in the specific activity and concentrations of glucose do not occur uniformly within the entire glucose pool. To compensate for non-uniform mixing, the non-steadystate term of the equation was multiplied by a correction factor (pool fraction) of $0.65[20,21]$. During the glucose infusions the tate of $R_{a}$ was calculated by subtracting the rate of infusion of exogenous glucose from the tracer-determined total rate of glucose production. As glucose utilisation reached steady-state during the second hour of each clamp, the results during that period have been used in the calculations.

\section{Statistical analysis}

Data are shown as means \pm SEM. Significances of differences were evaluated by Student's t-test for paired data.

\section{Results}

\section{Hypoglycaemia}

The glucose levels were similar in the two studies at the end of clamp I (placebo $4.4 \pm 0.1$, propranolol $4.0 \pm$ $0.2 \mathrm{mmol} / \mathrm{l}$ ). After stopping the glucose and increasing the insulin infusion, the blood glucose levels decreased rapidly and nadir was reached $20 \mathrm{~min}$ after the high insulin infusion rate had been stopped (Fig. 2a). The mean glucose nadir levels were similar in both studies (placebo 1.9 \pm 0.1 , propranolol $1.9 \pm 0.2 \mathrm{mmol} / \mathrm{l}$ ). However, glucose had to be given to one of the patients during propranolol infusion as spontaneous glucose recovery did not occur.

The levels of free insulin were similar in the two groups both before the hypoglycaemia, i.e. at the end of clamp I (placebo $23 \pm 1$, propranolol $25 \pm 1 \mathrm{mU} / 1$ ), during the high insulin infusion rate which induced the hypoglycaemia (placebo $92 \pm 10$, propranolol $89 \pm$ $13 \mathrm{mU} / 1)$ as well as during the recovery phase (Fig. 2a).

The adrenaline levels were also similar before the study. The highest adrenaline levels were measured 20 min after glucose nadir and they were significantly higher during infusion of propranolol than in the placebo group (placebo 2.20 \pm 0.35 , propranolol $7.14 \pm 1.4 \mathrm{nmol} / 1, \mathrm{p}<0.02$ ) (Fig. 2b). The fasting glucagon levels were similar in both groups. The highest lev-
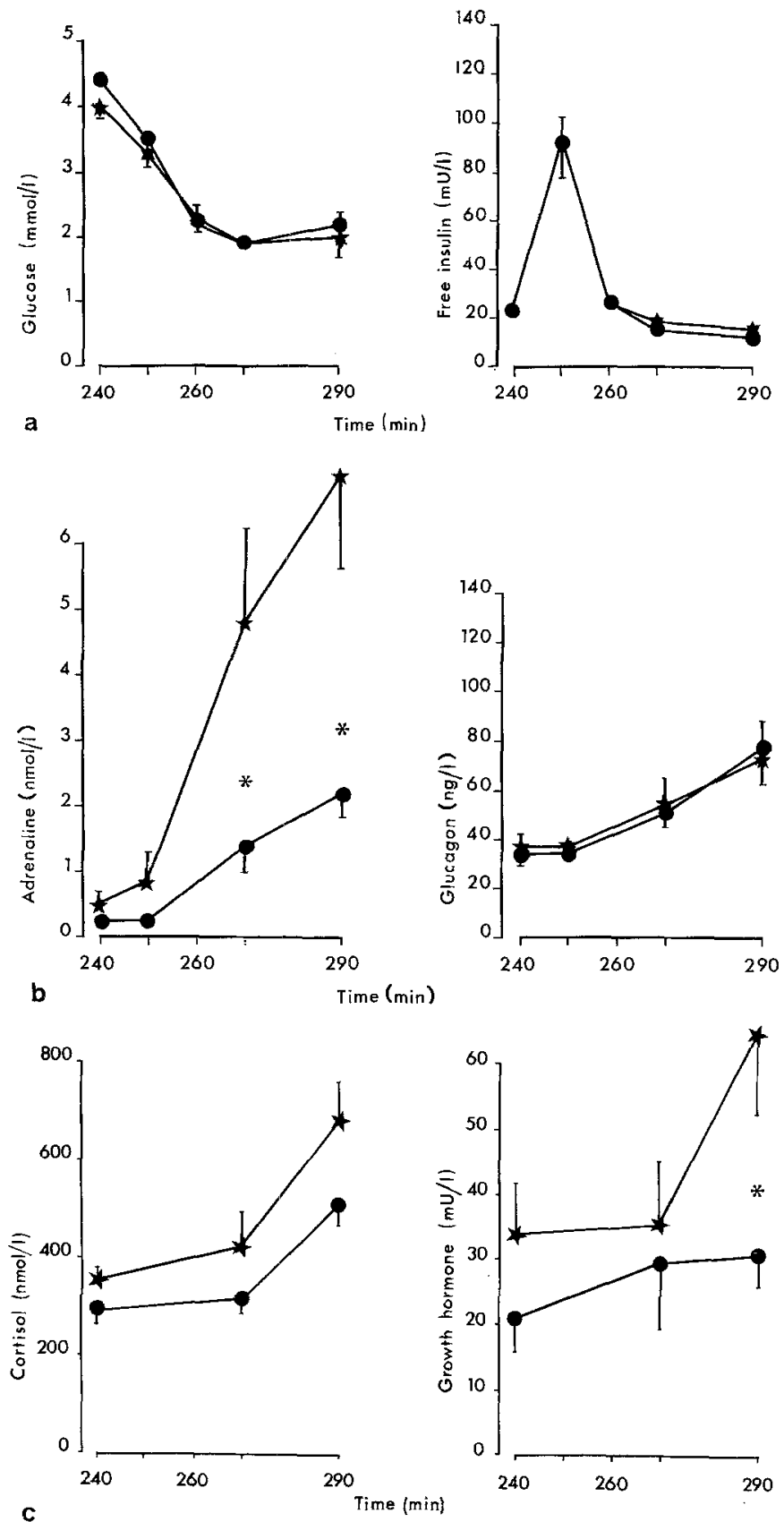

Fig. 2. Glucose and free insulin levels (a), adrenaline and glucagon (b), cortisol and growth hormone levels (c), during the hypoglycaemia. ( ) indicates placebo treatment and $(\star)$ propranolol treatment. ${ }^{*} p<0.05$

els, similar to adrenaline, were measured 20 min after glucose nadir. The growth hormone levels were significantly higher $(\mathrm{p}<0.05)$ during propranolol infusion, while no difference between the groups was seen for cortisol (Fig. 2c).

\section{Euglycaemic clamps}

The glucose levels were similar during the clamps (placebo clamp I $4.4 \pm 0.02$, clamp II $4.4 \pm 0.08$; propranolol clamp I $4.2 \pm 0.10$, clamp II $4.2 \pm 0.10 \mathrm{mmol} /$ 
1). The free insulin levels remained stable during the clamps and were similar in both groups (Fig.3). The insulin effect, measured as steady state glucose infusion rate (SSGIR), was significantly $(p<0.02)$ lower in the placebo group after hypoglycaemia (clamp II $1.26 \pm 0.08 \mathrm{mg} \cdot \mathrm{kg}^{-1} \cdot \mathrm{min}^{-1}$ ) when compared to before the hypoglycaemia (clamp I $2.58 \pm 0.32 \mathrm{mg} \cdot \mathrm{kg}^{-1}$. $\min ^{-1}$ ) (Fig. 4a). However, SSGIR was similar both be-

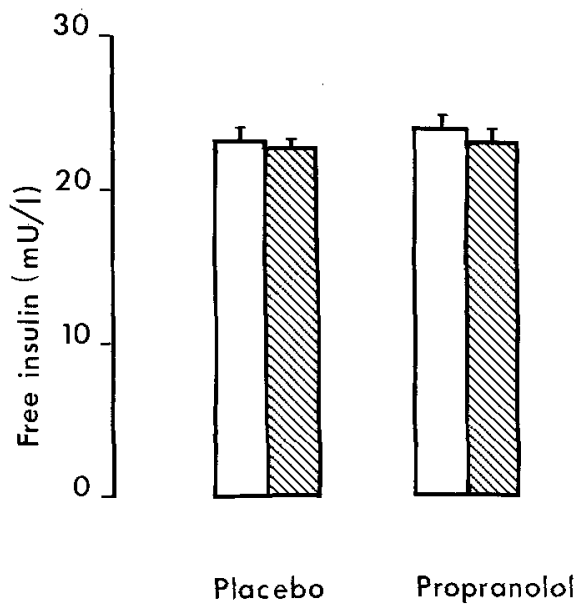

Fig.3. Free insulin levels during the euglycaemic clamps.

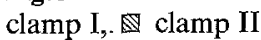
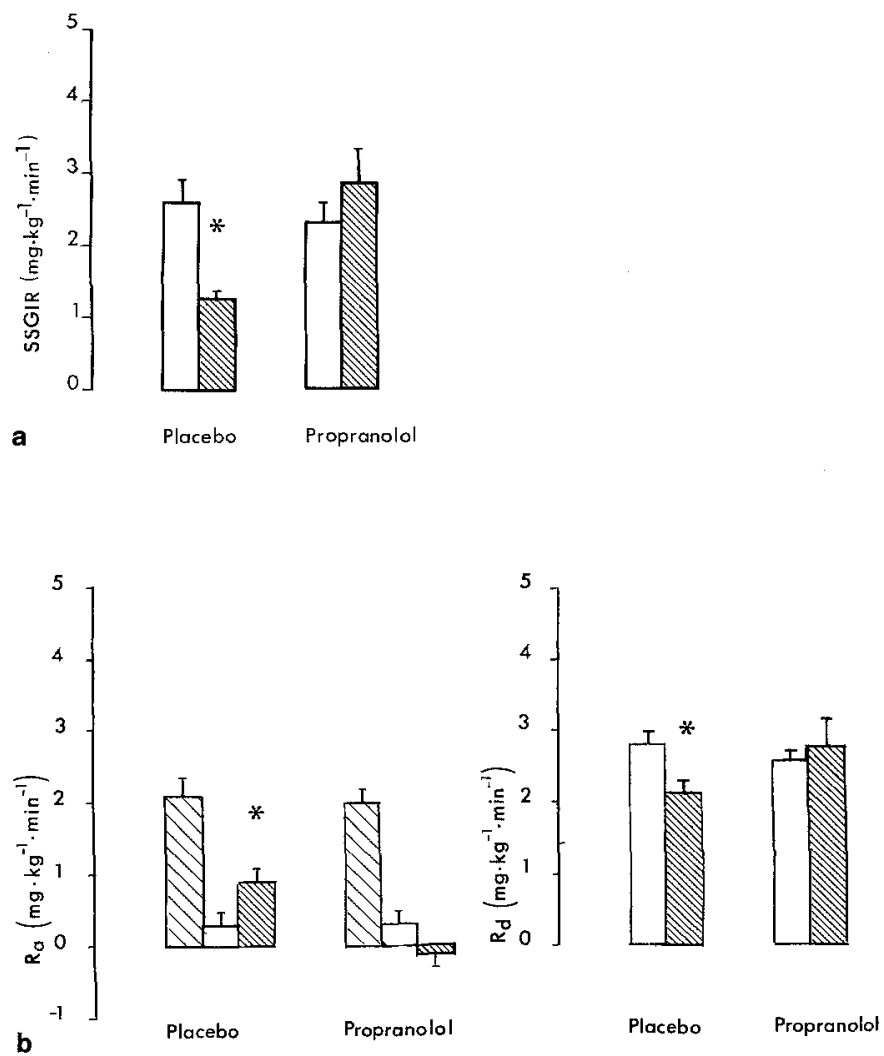

Fig.4. a Steady state glucose infusion rates (SSGIR) during euglycaemic clamps I and II in the two treatment groups. $\square$ clamp I, clamp II. $* p<0.02$. b Glucose production $\left(\mathrm{R}_{\mathrm{a}}\right)$ (left) and glucose disposal $\left(R_{d}\right)$ (right) in the two treatment groups before euglycaemic clamping $(\nabla)$, during clamp I before hypoglycaemia $(\square)$ and during clamp II after hypoglycaemia $(\mathbb{\mathbb { N }}) .{ }^{*} p<0.05$ fore and after the hypoglycaemia during propranolol infusion (clamp I $2.29 \pm 0.29$, clamp II $2.85 \pm$ $0.56 \mathrm{mg} \cdot \mathrm{kg}^{-1} \cdot \mathrm{min}^{-1}$ ) (Fig. $4 \mathrm{a}$ ).

\section{Glucose production}

$R_{a}$ was similar in both groups before clamp I (placebo $2.15 \pm 0.21$, propranolol $2.00 \pm 0.22 \mathrm{mg} \cdot \mathrm{kg}^{-1} \cdot \mathrm{min}^{-1}$ ) (Fig. 4b). During clamp I glucose production decreased correspondingly in both groups (placebo $0.29 \pm 0.21$, propranolol $0.31 \pm 0.17 \mathrm{mg} \cdot \mathrm{kg}^{-1} \cdot \mathrm{min}^{-1}$ ). However, after the hypoglycaemia glucose production was elevated in the placebo group (clamp II $0.86 \pm$ $\left.0.19 \mathrm{mg} \cdot \mathrm{kg}^{-1} \cdot \mathrm{min}^{-1}\right)$ and was significantly $(p<0.05)$ higher than during clamp I. Such an increase in glucose production was not seen if propranolol was infused (Fig. 4b).

\section{Glucose utilisation}

$\mathrm{R}_{\mathrm{d}}$ increased to a similar extent in both groups during clamp I (Fig.4b). However, in the placebo group $R_{d}$ was significantly lower after than before the hypoglycaemia (clamp I $2.84 \pm 0.26$, clamp II $2.13 \pm 0.23 \mathrm{mg}$. $\left.\mathrm{kg}^{-1} \cdot \min ^{-1}, p<0.05\right)$. This insulin antagonistic effect of the hypoglycaemia on glucose utilisation was not seen during propranolol infusion (Fig. 4b).

The counterregulatory hormone levels were, with the exception of adrenaline, similar during both clamps in the placebo group (Table 2). However, the adrenaline levels were slightly elevated following the hypoglycaemia (Table 2). This was even more pronounced in the propranolol group where the growth hormone levels were also significantly higher during clamp II as compared to clamp I (Table 2).

\section{Heart rate}

The heart rates before the clamps were similar in both groups (placebo $63 \pm 4$, propranolol $66 \pm 4$ beats $/ \mathrm{min}$ ). The heart rate increased during hypoglycaemia when placebo was infused (maximal rate $84 \pm 2$ beats $/ \mathrm{min}$ ) but actually decreased when propranolol was infused ( $55 \pm 3$ beats $/ \mathrm{min})$.

\section{Discussion}

The present study clearly shows that hypoglycaemia in Type 1 diabetic patients is followed by a prolonged insulin resistance. The insulin resistance is, at least in this early phase, due to $\beta$-adrenergic stimulation and affects both glucose production and utilisation. The clinical importance of this posthypoglycaemic insulin resistance has recently been documented by Perriello et al. [22] who found elevated glucose levels following a nocturnal hypoglycaemia particularly in the postprandial state. 
Table 2. Counterregulatory hormones before and during euglycaemic clamps I and II

\begin{tabular}{|c|c|c|c|c|c|c|}
\hline & \multicolumn{3}{|l|}{ Placebo } & \multicolumn{3}{|l|}{ Propranolol } \\
\hline & Before & Clamp I & Clamp II & Before & Clamp I & Clamp II \\
\hline Adrenaline (nmol/1) & $0.15 \pm 0.02$ & $0.22 \pm 0.02$ & $0.31 \pm 0.04^{a}$ & $0.15 \pm 0.01$ & $0.44 \pm 0.13$ & $0.65 \pm 0.12^{\mathrm{a}}$ \\
\hline Noradrenaline (nmol/1) & $1.07 \pm 0.15$ & $1.10 \pm 0.13$ & $1.41 \pm 0.13$ & $1.05 \pm 0.12$ & $1.48 \pm 0.12$ & $1.57 \pm 0.10$ \\
\hline Glucagon (ng/l) & $47 \pm 3$ & $35 \pm 3$ & $38 \pm 5$ & \pm 4 & \pm 4 & \pm 3 \\
\hline Cortisol (nmol/1) & $273 \pm 28$ & \pm 27 & $330 \pm 62$ & \pm 26 & \pm 24 & \pm 73 \\
\hline Growth hormone $(\mathrm{mU} / \mathrm{l})$ & $13.6 \pm 4.4$ & $20.8 \pm 5.1$ & $22.1 \pm 10.9$ & $9.9 \pm 2.8$ & $34.0 \pm 10.0$ & $48.2 \pm 12.0^{\mathrm{a}}$ \\
\hline
\end{tabular}

Results are means \pm SEM

${ }^{\text {a }} p<0.05$ compared with clamp I

The typical hypoglycaemic episode in the awake Type 1 diabetic patient is of relatively short duration since the patients ingest carbohydrates as soon as possible to restore normoglycaemia. The design of the present study, where glucose was given to normalise the glucose levels seems, therefore, appropriate and relevant for the normal clinical situation. The insulin concentrations used in the clamps were also low and similar to the levels frequently seen in Type 1 diabetic patients during both conventional insulin therapy and continuous subcutaneous insulin infusion [23, 24].

Spontaneous glucose counterregulation was slow in these Type 1 diabetic patients as compared to a recent study of similar design in non-diabetic subjects [25]. The fact that glucose counterregulation is impaired in Type 1 diabetes is in accordance with a number of previous studies [7, 26-30]. A further deterioration was found during infusion of propranolol. This has also been reported in several recent studies [28-30]. The levels of counterregulatory hormones increased during the hypoglycaemia in both groups. As expected, the increase of adrenaline was more pronounced during propranolol infusion. This is due to a lower clearance rather than an increased release [31]. The growth hormone levels were also higher during the hypoglycaemia in the propranolol group. This is probably due to the higher adrenaline levels and an enhanced $\alpha$-receptor stimulation. Similar results have been found during hypoglycaemia with both the relatively cardioselective $\left(\beta_{1}\right)$ - and the nonselective $\left(\beta_{1}+\beta_{2}\right)$-antagonists [32-34].

The insulin effect on glucose disposal remains unchanged or even increases with time during a euglycaemic clamp [35]. Thus, the insulin resistance seen in the placebo group during clamp II must have been elicited by the hypoglycaemia. The elevated insulin infusion used to induce the hypoglycaemia can also be disregarded in this respect. This is supported by the control experiments in a similar study in healthy subjects where the same insulin dose was given but hypoglycaemia was prevented [25]. The fact that propranolol prevented the development of the insulin resistance further corroborates this.

The early posthypoglycaemic insulin resistance can thus be entirely explained by an increased $\beta$-adrenergic stimulation during hypoglycaemia. The adrenaline, but not noradrenaline, levels were slightly higher during clamp II as compared to clamp I in both groups. However, the levels were probably much too low to make any important contribution to the insulin resistance [36]. A more likely possibility is a sustained insulin-antagonistic effect of the elevated catecholamine levels. Studies in vitro have shown that catecholamines can inhibit insulin binding to both rat $[37,38]$ and human fat cells [39] and that this effect becomes more pronounced with time [37]. Insulin-stimulated glucose transport is also decreased by $\beta$-adrenergic stimulation [40-42].

The insulin resistance induced by hypoglycaemia encompassed both glucose production and glucose utilisation. Corresponding results with an insulin-antagonistic effect of $\beta$-adrenergic stimulation on both glucose production and utilisation during a euglycaemic clamp have recently been obtained in healthy subjects [43].

Glucagon is of major importance for glucose counter-regulation during hypoglycaemia [2, 3]. However, the release of this hormone is impaired in Type 1 diabetic patients; this is one important reason for the slower glucose recovery in these patients $[26,27]$. The impaired glucagon release makes it unlikely that this hormone significantly contributes to the posthypoglycaemic insulin resistance in Type 1 diabetes. The results of the present study are clearly in agreement with this concept.

Both cortisol and growth hormone have insulin-antagonistic effects and could, therefore, be of importance for posthypoglycaemic insulin resistance [44, 45]. However, since the cortisol levels were similar in both treatment groups and the growth hormone levels higher in the propranolol group these hormones do not appear to significantly contribute to the insulin resistance under the current experimental conditions. However, there is a time lag of $2-3 \mathrm{~h}$ before the insulin-antagonistic effect of growth hormone becomes apparent [46]. This hormone may, therefore, become important at a later stage.

In conclusion, hypoglycaemia is followed by a prolonged and marked insulin resistance which is due to $\beta$-adrenergic stimulation. This insulin resistance may provide an important explanation for the posthypoglycaemic hyperglycaemia. Further studies in progress are aimed at evaluating the clinical usefulness of treating 
Type 1 diabetic patients with an appropriate $\beta$-blocking agent.

Acknowledgements. This study was supported by grants from the Swedish Medical Research Council (project 3506), Tore Nilssons Fund, The Swedish Diabetes Association and Göteborgs Läkaresällskap. The excellent technical assistance by Ms U.Skredsvik, R.N., and the secreterial aid by Ms H.Carlsten is gratefully acknowledged.

\section{References}

1. Somogyi M (1959) Exacerbation of diabetes by excess insulin action. Am J Med 26: 169-191

2. Gerich J, Davis J, Lorenzi M, Rizza R, Bohannon N, Karam J, Lewis S, Kaplan R, Schultz T, Cryer P (1979) Hormonal mechanisms of recovery from insulin-induced hypoglycaemia in man. Am J Physiol 236 (4): E380-E385

3. Rizza R, Cryer PE, Gerich JE (1979) Role of glucagon, catecholamines, and growth hormone in human glucose counteregulation. J Clin Invest 64: 62-71

4. Garber AJ, Cryer PE, Santiago JV, Haymond MW, Pagliara AS, Kipnis DM (1976) The role of adrenergic mechanisms in the substrate and hormonal response to insulin-induced hypoglycemia in man. J Clin Invest 58:7-15

5. Bolli GB, Dimitriadis GD, Pehling GB, Baker BA, Morey WH, Cryer PE, Gerich JE (1984) Abnormal glucose counterregulation after subcutaneous insulin in insulin-dependent diabetes mellitus. N Engl J Med 310: 1706-1711

6. Gale EAM, Kurtz AB, Tattersall RB (1980) In search of the Somogyi effect. Lancet 2: 279-282

7. Bolli GB, Gottesman IS, Campbell PJ, Haymond MW, Cryer PE, Gerich JE (1984) Glucose counterregulation and waning of insulin in the Somogyi phenomenon (posthypoglycemic hyperglycemia). N Engl J Med 311: 1214-1219

8. The DCCT Research Group (1984) Results f feasibility phase of the diabetes control and complications trial (DCCT): glycemic control, follow-up and complications of therapy. Diabetes 35 [Suppl 1]: $10 \mathrm{~A}$

9. Dahl-Jörgensen, K, Brichmann-Hansen O, Hanssen KF, Ganes T, Kierulf P, Smeland E, Sandvik L, Aagenaes Ö (1986) Effect of near normoglycaemia for two years on progression of early diabetic retinopathy, nephropathy, and neuropathy: the Oslo study. Br Med J 293: 1195-1199

10. National diabetes data group (1979) Classification and diagnosis of diabetes mellitus and other categories of glucose intolerance. Diabetes 28: 1039-1057

11. Ewing DJ, Campbell IW, Murray A, Neilson JMM, Clarke BF (1978) Immediate heart-rate response to standing: simple test for autonomic neuropathy in diabetes. Br Med J 1: 145-147

12. Mackay JD, Page M McB, Cambridge J, Watkins PJ (1980) Diabetic autonomic neuropathy. Diabetologia 18: 471-478

13. De Fronzo RA, Tobin JD, Andres R (1979) Glucose clamp technique: a method for quantifying insulin secretion and resistance. Am J Physiol 237: E214-223

14. Kuzuya H, Blix PM, Horowitz DL, Steiner DF, Rubenstein AH (1979) Determination of free and total insulin and C-peptide in insulin-treated diabetics. Diabetes 26: 22-29

15. von Schenck H (1977) Production and characterization of an antiserum against pancreatic glucagon. Clin Chim Acta 80: 455-463

16. von Schenck, Nilsson U (1981) Radioimmunoassay of extracted glucagon compared with three non-extraction assays. Clin Chim Acta 109: 182-191

17. Eriksson BM (1981) Aluminium foil instead of glass plates for thinlayer chromatography in radioenzymatic assay. Clin Chem 27: $341-342$
18. Holme I (1980) Determination of HbAlc with a cation exchange (mono-S) method. Academic dissertation, University of Gothenburg

19. DeBodo RCR, Steele N, Altszuler N, Dunn A, Bishop JS (1963) On the hormonal regulation of carbohydrate metabolism. Studies with $C^{14}$-glucose. Recent Prog Horm Res 19: 445-488

20. Cowan JS, Hetenyi G (1971) Glucoregulatory responses in nor$\mathrm{mal}$ and diabetic dogs recorded by a new tracer method. Metabolism 20: 360-372

21. Radziuk J, Norwich KM, Vranic M (1978) Experimental validation of measurements of glucose turn-over in non-steady state. Am J Physiol 234: E84-E93

22. Perriello G, De Feo P, Calcinaro F, Ventura MM, Basta G, Torlone E, Santeusanio F, Brunetti P, Bolli GB (1987) Nocturnal hypoglycemia exaggerates fasting and postbreakfast hyperglycemia in CSII-treated IDDM. Diabetes 36: [Suppl 1] $3 \mathrm{~A}$

23. Buysschaert M, Marchand E, Ketelslegers JM, Lambert AE (1983) Comparison of plasma glucose and plasma free insulin during CSII and intensified conventional insulin therapy. Diabetes Care 6: 1-5

24. Bending JJ, Pickup JC, Andrea BM, Collins CG, Keen H (1985) Rarity of a marked "dawn phenomen" in diabetic subjects treated by continuous subcutaneous insulin infusion. Diabetes Care 8: $28-44$

25. Attvall S, Eriksson B-M, Fowelin J, von Schenck H, Lager I, Smith U (1987) Early posthypoglycemic insulin resistance in man is mainly an effect of $\beta$-adrenergic stimulation. J Clin Invest 80 : $437-442$

26. Lager I, von Schenck H, Smith U (1984) Improved but not normalized glucose counter-regulation during glucagon infusion in type I (insulin-dependent) diabetes. Diabetologia 26: 337 -342

27. Bolli G, De Feo P, Compagnucci P, Cartechini MG, Angeletti G, Santeusanio F, Brunetti P, Gerich JE (1983) Abnormal glucose counterregulation in insulin-dependent diabetes mellitus. Diabetes 32: 134-141

28. Lager I, Blohmé $G$, Smith U (1979) Effect of cardioselective and non-selective $\beta$-blockade on the hypoglycaemic response in insulin-dependent diabetics. Lancet 1: 458-462

29. Popp DA, Shah SD, Cryer PE (1982) Role of epinephrinemediated $\beta$-adrenergic mechanisms in hypoglycemic glucose counterregulation and posthypoglycemic hyperglycemia in insulin-dependent diabetes mellitus. J Clin Invest 69: 315-326

30. De Feo P, Bolli G, Perriello G, De Cosmo S, Compagnunucci $P$, Angeletti G, Santeusanio F, Gerich JE, Motolese M, Brunetti P (1983) The adrenergic contribution to glucose counterregulation in type I diabetes mellitus. Diabetes $32: 887-893$

31. Gerich JE, Cryer P, Rizza R (1980) Hormonal mechanisms in acute glucose counterregulation: the relative roles of glucagon, epinephrine, norepinephrine, growth hormone, and cortisol. Metabolism 29: 1114-1118

32. Lager I, Jagenburg $R$, von Schenck $H$, Smith U (1980) Effect of beta-blockade on hormone release during hypoglycaemia in insulin-dependent diabetics. Acta Endocrinol 95: 364-371

33. Kleinbaum J, Shamoon H (1984) Effect of propranolol on delayed glucose recovery after insulin-induced hypoglycaemia in normal and diabetic subjects. Diabetes Care 7: 155-162

34. Popp DA, Tse TF, Shah SD, Clutter WE, Cryer PE (1984) Oral propranolol and metoprolol both impair glucose recovery from insulin-induced hypoglycemia in insulin-dependent diabetes mellitus. Diabetes Care 7: 243-247

35. Doberne L, Greenfield MS, Schulz B, Reaven GM (1981) Enhanced glucose utilization during prolonged glucose clamp studies. Diabetes 30: 829-835

36. Clutter WE, Bier DM, Shah SD, Cryer PE (1980) Epinephrine plasma metabolic clearance rates and physiological thresholds for metabolic and hemodynamic actions in man. J Clin Invest 66: 94-101

37. Lönnroth P, Smith U (1983) Beta-adrenergic dependent downregulation of insulin binding in rat adipocytes. Biochem Biophys Res Commun 112: 972-979 
38. Pessin JE, Gitomer W, Oka Y, Oppenheimer CL, Czech MP (1983) $\beta$-adrenergic regulation of insulin and epidermal growth factor receptors in rat adipocytes. J Biol Chem 258: 7386-7394

39. Lönnroth P, Wesslau C, Stenström G, Tisell LE, Smith U (1985) Reduced insulin binding to human fat cells following beta-adrenergic stimulation - experimental evidence and studies in patients with a phaeochromocytoma. Diabetologia 28: 901-906

40. Green A (1983) Catecholamines inhibit insulin-stimulated glucose transport in adipocytes in the presence of adenosine deaminase. FEBS Lett 152: 261-264

41. Smith U, Kuroda M, Simpson IA (1984) Counter-regulation of insulin stimulated glucose transport by catecholamines in the isolated rat adipose cell. J Biol Chem 259: 8758-8763

42. Kirsch DM, Baumgartner M, Rinninger T, Kemmler W, Häring HU (1983) Catecholamine-induced resistance of glucose transport in isolated rat adipocytes. Biochem $\mathrm{J} 216: 737-745$

43. Lager I, Attvall S, Eriksson BM, von Schenck H, Smith U (1986) Studies on the insulin-antagonistic effect of catecholamines in normal man. Diabetologia 29: 409-416
44. Rizza RA, Mandarino LJ, Gerich JE (1982) Cortisol induced insulin resistance in man: impaired suppression of glucose production and stimulation of glucose utilization due to a postreceptor defect of insulin action. J Clin Endocrinol Metab 54: 131-138

45. Rizza RA, Mandarino LJ, Gerich JE (1982) Effects of growth hormone in insulin action in man. Diabetes 31: 662-669

46. Brattusch-Marrain PR, Smith D, De Fronzo RA (1982) The effect of growth hormone on glucose metabolism and insulin secretion in man. J Clin Endocrinol Metab 55: 973-982

Received: 10 March 1987

and in revised form: 24 July 1987

Dr. Ibe Lager

Department of Medicine II

Sahlgren's Hospital

S-41345 Gothenburg

Sweden 